\title{
Science advisers resign over smog policy
}

San Francisco. Nine of the 11 scientific advisers to southern California's smog control agency resigned last week, complaining of increasingly lenient policies that they said put public health at risk. They specifically criticized a new plan to control smog, announced earlier this month, which they said would abandon significant new control measures.

The South Coast Air Quality Management District has been a world leader in the development of regulations and technology to control air pollution. But in recent years the district has cut spending and shifted its regulatory posture to ease the pressure on businesses and motorists to cut emissions.

The specialists who resigned from the agency's advisory committee included chemists, economists, health experts and environmentalists. They said they believed that the agency's policies were no longer directed towards achieving healthy air quality, especially with regard to meeting federal government standards on ozone and fine particles.

In their resignation letter, eight members of the group pointed to signs of "waffling" on policy, including "an absence of enforcement", "a proposal to dismantle the world's premier air monitoring network" and the "absence of concerted rule-making in the proposed new plan". The ninth adviser resigned in a separate letter that agreed with the others' concerns.

Reactions among the governing board for the district ranged from shock and distress to relief, says Tom Eichhorn, director of communications. One board member called the resignations "a breath of fresh air", Eichhorn says. Senator Ray Haynes (Republican, Riverside) told the Los Angeles Times that he had been sceptical about the value of the panel and concerned about the misuse of science in environmental management.

But Larry Berg is an environmental and energy consultant and expert in political science who served on the board for 11 years. He says he expects the resignations to stimulate the public, environmentalists and academics to become more vocal in opposition to the board's changing posture. "This is a very significant event," he says.

Berg, who left the board in 1993, criticizes the smog control plan as an antiscience, anti-intellectual approach which discarded peer-reviewed studies in deciding what level of pollution is a threat to public health and how to reduce it.

The plan is based on a new analysis which concludes that Los Angeles, Orange, Riverside and San Bernardino counties will meet federal guidelines for pollution control by 2006 without bringing in controversial measures such as cutting the number of vehicle trips.

The draft plan says: "With the new data and tools, it can now be determined that fewer additional reductions in emissions are needed to meet the federal ambient air quality deadlines." But it acknowledges that southern California still has the worst air quality in the United States.

Those who resigned from the advisory panel, who said they had no part in developing the plan, criticized its predictions as over-optimistic. Most had been on the advisory committee for at least a decade.

The district had pioneered pollution control, reducing emissions by 50 per cent over ten years. Observers say it now appears to be bowing to business and political interests which had blamed its policies for severe job losses.

Sally Lehrman

\section{Japan shuns radishes after 'possible link' to $E$. coli}

Tokyo. Japan's health ministry has set off a public scare by announcing that white radish sprouts, a commonly eaten vegetable in Japan, may be one source of the recent mass infection of schoolchildren with a potentially deadly strain of Escherichia coli.

The statement has also stirred up controversy because there is as yet no direct evidence linking the radishes to the poisoning outbreak. The premature announcement reflects public pressure on the ministry to trace the source of infection, which has caused sickness in more than 9,000 people, most of them children, and killed nine.

Last week the ministry released an interim report suggesting that white radish sprouts (kaiware daikon) produced by a farm in Habikino, near Osaka, may be the source of the 0157 strain of $E$. coli which caused food poisoning in July among more than 6,000 schoolchildren in Sakai city, also near Osaka, and at a nursing home in Habikino (see Nature 382, 290; 1996).

But the evidence is only circumstantial. The $E$. coli has not been detected in the radish sprouts or at the farm. The ministry's investigation has simply established that the sprouts were common to meals eaten at schools in Sakai and at the nursing home just before the outbreak, and that the DNA make-up of the bacteria at the two locations is very similar, suggesting a common source of infection.
Despite the lack of firm evidence, supermarket chains have reacted by taking radish sprouts off their shelves, regardless of origin, and restaurants have taken the vegetable off their menus. Radish farmers throughout

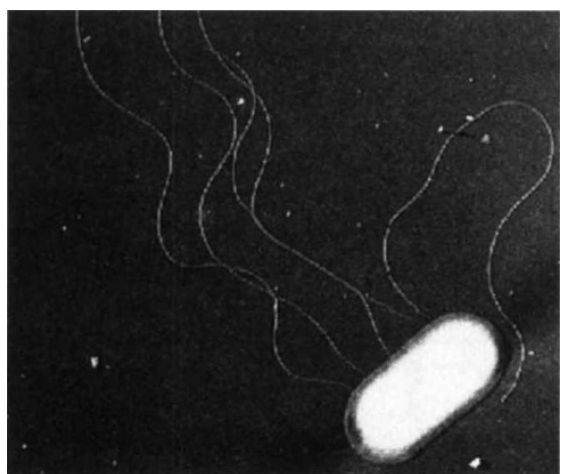

Root of the problem: evidence linking $E$. coli 0157 and the radishes is circumstantial.

Japan are protesting that the ministry's action threatens them with financial ruin.

Naoto Kan, the health minister, reportedly made a "political decision" to announce the ministry's suspicions before gaining hard evidence. "We cannot conclude that white radish sprouts were the contagion source, but we cannot rule out the possibility that they were the source of infection," Cabinet members reported him as saying at the time the ministry's report was released.

Kan is no stranger to controversy. Earlier this year he received wide public praise for exposing his ministry's failure to halt the spread of HIV infection among Japanese haemophiliacs in the $1980 \mathrm{~s}$, but he is being severely criticized on this occasion.

As public confidence in sprouts collapsed, Kan stressed that the vegetable was only suspected of being the source. "Since 0157 has not been detected in the radish sprouts and production facilities, we don't have all the objective facts," he admitted at a meeting of the health committee of the lower house of the Japanese parliament.

Scientists have expressed doubts that the radish sprouts are the primary source of infection. The 0157 strain of $E$. coli occurs naturally in the intestines of cows and can be carried in the animals' meat or faeces. Secondary contamination can occur when other food comes into contact with contaminated meat or the bacteria are transmitted by infected humans.

Radish sprouts are grown in urethane sponges under hydroponic cultivation. An inspection of the Habikino farm on 24 July, after the outbreak of food poisoning, failed to detect the bacteria in either the sprouts, seeds or water for the plant. A second, more thorough, inspection has been made, but results are not yet available. Very small numbers of the bacteria - probably as few as ten - can cause infection, so it is difficult to trace their source.

David Swinbanks 